\title{
POTENSI FILTRAT DAUN SUKUN (Artocarpus altilis) SEBAGAI BIOINSEKTISIDA LALAT RUMAH (Musca domestica)
}

Ani Yuanita*, Ngadino, Suprijandani

Jurusan Kesehatan Lingkungan Poltekkes Kemenkes Surabaya

*Email korespondensi: aniyuanita23@gmail.com

\begin{abstract}
ABSTRAK
Lalat rumah merupakan vektor penyebaran penyakit secara mekanis. Pengendalian lalat dengan menggunakan insektisida kimia secara kontinyu mengakibatkan resistensi pada lalat dan dapat mencemari lingkungan. Alternatif lain yang dapat digunakan insektisida nabati yaitu berasal dari tumbuhan daun sukun. Hasil fitokimia daun sukun memiliki kandungan Flavonoid 1,88\%, Saponin 2,26\%, dan Tanin 1,05\%. Tujuan penelitian ini yaitu untuk mengetahui potensi filtrat daun sukun sebagai bioinsektisida lalat rumah (Musca domestica).

Jenis penelitian ini menggunakan eksperimen murni dengan post test only control grup design dengan konsentrasi 2,5\%,5\%, 7,5\%, kontrol dan 5 kali replikasi. Jumlah lalat rumah yang digunakan yaiu 375 ekor. Data dianalisis menggunakan uji Kruskal Wallis.

Hasil penelitian menunjukkan diperoleh $\mathrm{p}<0,05$ yang artinya ada perbedaan ratarata kematian lalat rumah dengan menggunakan berbagai konsentrasi setiap perlakuan. Uji probit didapatkan hasil Lethal Concentration (LC50) pada jam ke-1 yaitu pada konsentrasi 5,189\%, jam ke-12 yaitu pada konsentrasi 3,930\% dan jam ke-24 menunjukkan konsentrasi 3,086\%.

Kesimpulan penelitian ini adalah filtrat daun sukun dapat digunakan bioinsektisida lalat rumah. Saran bagi peneliti lain dapat melakukan penelitian yang sama dengan membandingkan dengan tumbuhan lain yang memiliki kandungan senyawa aktif yang berpotensi dalam membunuh lalat rumah (Musca domestica). Tumbuhan lain yang memiliki kandungan senyawa aktif lebih tinggi dapat digunakan sebagai rekomendasi insektisida nabati yang sifatnya bio-degradable (mudah terurai) di alam.
\end{abstract}

Kata kunci: Filtrat Daun Sukun, Bioinsektisida, Lalat Rumah (Muscadomestica)

\section{PENDAHULUAN}

Penyakit tular vektor merupakan penyakit berbasis lingkungan yang dipengaruhi oleh lingkungan fisik, biologi, maupun sosial. Lalat merupakan salah satu jenis serangga Arthropoda sebagai vektor dan pembawa penyakit (Permenkes RI, 2017). Lalat memiliki peran penting dalam masalah kesehatan masyarakat sebagai vektor mekanis (Safira, Nurmaini, \& Dharma, 2015). Vektor mekanis merupakan agent penyakit yang berada di dalam tubuh vektor tanpa mengalami perubahan (Martindah, 2016).

Beberapa spesies lalat yang mempunyai peran penting dalam masalah kesehatan masyarakat, diantaranya adalah Musca domestica (lalat rumah), Stomoxys calcitrans (lalat kandang), Lucilia sp. (lalat hijau), Sarcophaga sp. (lalat daging), dan Fannia sp (lalat kecil). Kelima jenis lalat tersebut, jumlah populasi lalat yang paling tinggi adalah lalat rumah (Musca domestica), dikarenakan hidupnya berdampingan dengan aktivitas manusia dan sumber makanannya sebagian besar terdapat pada makanan manusia (Rina, 2017). Lalat rumah (Musca domestica) sebagai vektor utama penyebaran penyakit yang ditularkan secara mekanis seperti disentri, diare, kolera, thypus dan penyakit saluran pencernaan lainnya (Prasetya, Yamtana, \& Amalia, 2015).

Upaya untuk menurunkan populasi lalat adalah dengan cara melakukan pengendalian vektor yang bertujuan untuk menurunkan populasi vektor serendah mungkin, sehingga keberadaannya tidak lagi berisiko untuk terjadinya penularan penyakit (Permenkes RI, 2017). Pengendalian lalat dapat dilakukan secara fisik, perbaikan sanitasi lingkungan, biologi, dan kimiawi. 
Pengendalian lalat secara umum yang dilakukan hingga saat ini adalah menggunakan insektisida. Penggunaan insektisida dapat memberikan hasil yang cepat dan nyata, namun insektisida bila digunakan dalam jangka panjang dan melebihi dosis anjuran akan berdampak negatif terhadap lingkungan dan kesehatan manusia (Safirah, Widodo, \& Budiyanto, 2016).

Penggunaan insektisida secara terus menerus akan menyebabkan lalat menjadi resisten dan terjadinya pencemaran lingkungan, sehingga perlu dicarikan solusi agar dampak tersebut dapat diminimalisir.

\section{METODE PENELITIAN}

Penelitian ini merupakan jenis penelitian eksperimen murni dengan menggunakan rancangan post test only control group design yang terdiri dari kelompok kontrol dan kelompok eksperimen (Notoatmodjo, 2012).

Objek penelitian ini adalah filtrat daun sukun (Artocarpus altilis) yang telah disemprotkan dengan variasi konsentrasi $2,5 \%$, 5\%, dan 7,5\%. Penelitian ini menggunakan 500 ekor lalat rumah (Musca domestica) dewasa dan dibagi menjadi 25 ekor pada masing-masing perlakuandengan pengulangan sebanyak 5 kali dan pengamatan kematian lalat rumah selama 24 jam.

Alat yang digunakan dalam pembuatan filtrat daun sukun yaitu timbangan analitik, blender, gelas ukur, kandang lalat rumah ukuran $30 \times 30 \times$ $30 \mathrm{~cm}^{3}$, aspirator, hygrometer untuk mengukur suhu dan kelembaban ruangan, counter, alat semprot, gunting.

Bahan yang digunakan dalam pembuatan filtrat daun sukun adalah daun sukun, lalat rumah dewasa yang adalah menggunakan bioinsektisida yang bersumber dari tanaman (Safirah, Widodo, \& Budiyanto, 2016). Bioinsektisida merupakan insektisida generasi baru untuk mengendalikan hama yang memanfaatkan jasa makhluk hidup. Sistem kerja bioinsektisida adalah tepat sasaran, bersifat ramah lingkungan, dan tidak menimbulkan residu layaknya pestisida kimia. Secara umum bioinsektisida menggunakan bahan alami seperti tumbuhan, salah satunya adalah tanaman sukun (Artocarpus altilis) (Yuningsih, 2016). Kandungan bahan aktif yang terdapat pada tanaman sukun (Artocarpus altilis) adalah saponin, tanin, flavonoid, riboflavin, asam hidrosianat, dan asetilkolin. Kandungan bahan aktif tanaman sukun diatas yang sudah terbukti dapat digunakan sebagai bioinsektisida adalah saponin, tanin, flavonoid (Hadawiah, 2017). Tujuan dari penelitian ini yaitu untuk mengetahui potensi filtrat daun sukun (Artocarpus altilis) sebagai bioinsektisida lalat rumah (Musca domestica).

Cara pembuatan filtrat daun sukun:

1. Siapkan daun sukun (Artocarpus altilis).

2. Cuci daun sukun hingga bersih.

3. Potong daun sukun menjadi kecilkecil agar mudah dihaluskan.

4. Timbang daun sukun sesuai dengan konsentrasi yang dibutuhkan

5. Memasukkan daun sukun yang sudah ditimbang ke dalam blender dan menuangkan aquadest sebanyak $200 \mathrm{ml}$.

6. Menyaring hasil blender daun sukun tersebut dengan menggunakan kain kasa.

7. Memasukkan hasil saringan ke dalam botol sprayer.

Langkah-langkah melakukan perlakuan yaitu antara lain:

1. Siapkan kotak pengujian dengan ukuran $30 \times 30 \times 30 \mathrm{~cm}^{3}$.

2. Ukur suhu dan kelembaban udara pada ruangan dengan menggunakan hygrometer. Suhu optimum berada di kisaran $20^{\circ} \mathrm{C} \quad-34^{\circ} \mathrm{C}$ dan kelembaban 45\%-90\%.

3. Ambil 25 ekor lalat rumah (Musca domestica) dengan menggunakan aspirator, kemudian masukkan ke dalam kotak pengujian dan beri label (A untuk pengulangan 1, B untuk pengulangan $2, C$ untuk pengulangan $3, \quad D$ untuk pengulangan 4 dan $E$ untuk pengulangan 5).

4. Semprotkan fitrat daun sukun dengan menggunakan alat semprot kedalam kotak pengujian yang 
sudah diisi dengan lalat rumah (Musca domestica).

5. Amati dan catat jumlah kematian lalat rumah (Musca domestica) selama 1×24 jam setelah penyemprotan.

6. Kemudian hitung dan catat kematian lalat rumah (Musca domestica) pada setiap kotak pengujian, serta amati kematian lalat rumah secara fisik dengan tanda- tanda lalat rumah tidak bergerak sama sekali walaupun telah mendapat rangsangan berupa sentuhan dan hembusan angin (Ar, 2016).

Teknik pengumpulan data diperoleh dari hasil pengamatan langsung yang dilakukan di Laboratorium Entomologi Jurusan Kesehatan Lingkungan Surabaya. Analisis data dalam penelitian ini menggunakan uji Kruskal wallis dan analisis probit.

HASIL DAN PEMBAHASAN

Tabel 1

REKAPITULASI HASIL PERLAKUAN JUMLAH KEMATIAN LALAT RUMAH

\begin{tabular}{|c|c|c|c|c|c|c|c|c|}
\hline \multirow[t]{2}{*}{ Replikasi } & \multirow[t]{2}{*}{$\sum_{\text {Uji }}$} & \multirow[t]{2}{*}{$\begin{array}{c}\text { Perlakua } \\
\mathrm{n}\end{array}$} & \multicolumn{2}{|c|}{$\begin{array}{c}\text { Kematian lalat } \\
\text { rumah jam ke- } \\
\underline{1} \\
\end{array}$} & \multicolumn{2}{|c|}{$\begin{array}{c}\text { Kematian } \\
\text { lalat rumah } \\
\text { jam ke-12 }\end{array}$} & \multicolumn{2}{|c|}{$\begin{array}{c}\text { Kematian lalat } \\
\text { rumah jam ke- } \\
\underline{24}\end{array}$} \\
\hline & & & $\Sigma$ & $\%$ & $\Sigma$ & $\%$ & $\Sigma$ & $\%$ \\
\hline \multirow[t]{4}{*}{$\mathrm{I}$} & 25 & Kontrol $(-)$ & 0 & 0 & 0 & 0 & 0 & 0 \\
\hline & 25 & $2,5 \%$ & 8 & 32 & 9 & 36 & 11 & 44 \\
\hline & 25 & $5 \%$ & 12 & 48 & 14 & 56 & 16 & 64 \\
\hline & 25 & $7,5 \%$ & 14 & 56 & 18 & 72 & 20 & 80 \\
\hline \multirow[t]{4}{*}{ II } & 25 & Kontrol (-) & 0 & 0 & 0 & 0 & 0 & 0 \\
\hline & 25 & $2,5 \%$ & 7 & 28 & 8 & 32 & 10 & 40 \\
\hline & 25 & $5 \%$ & 13 & 52 & 15 & 60 & 17 & 68 \\
\hline & 25 & $7,5 \%$ & 15 & 60 & 19 & 76 & 22 & 88 \\
\hline \multirow[t]{4}{*}{ III } & 25 & Kontrol (-) & 0 & 0 & 0 & 0 & 0 & 0 \\
\hline & 25 & $2,5 \%$ & 6 & 24 & 8 & 32 & 11 & 44 \\
\hline & 25 & $5 \%$ & 12 & 48 & 13 & 52 & 15 & 60 \\
\hline & 25 & $7,5 \%$ & 13 & 52 & 16 & 64 & 21 & 84 \\
\hline \multirow[t]{4}{*}{ IV } & 25 & Kontrol (-) & 0 & 0 & 0 & 0 & 0 & 0 \\
\hline & 25 & $2,5 \%$ & 9 & 36 & 10 & 40 & 11 & 44 \\
\hline & 25 & $5 \%$ & 14 & 56 & 16 & 64 & 19 & 76 \\
\hline & 25 & $7,5 \%$ & 16 & 64 & 17 & 68 & 20 & 80 \\
\hline \multirow[t]{4}{*}{ V } & 25 & Kontrol (-) & 0 & 0 & 0 & 0 & 0 & 0 \\
\hline & 25 & $2,5 \%$ & 8 & 32 & 9 & 36 & 10 & 40 \\
\hline & 25 & $5 \%$ & 13 & 52 & 14 & 56 & 16 & 64 \\
\hline & 25 & $7,5 \%$ & 15 & 60 & 19 & 76 & 22 & 88 \\
\hline
\end{tabular}


Umur lalat merupakan faktor yang berpengaruh terhadap daya tahan lalat, sehingga umur lalat rumah (Musca domestica) yang digunakan dalam penelitian ini adalah rentang usia 2-4 hari yang merupakan rentang umur terbaik dari umur lalat dimana ketahanan tubuh lalat rumah masih kuat dan sudah produktif.

Hasil penelitian ini dilakukan pemaparan filtrat daun sukun (Artocarpus altilis) sebagai bioinsektisida lalat rumah (Musca domestica) dengan waktu pengamatan 1, 12, dan 24 jam dengan menggunakan konsentrasi sebesar 2,5\%, 5\%, dan 7,5\% dengan replikasi sebanyak 5 kali. Hasil penelitian dapat diketahui bahwa pada konsentrasi filtrat daun sukun 2,5\% menunjukkan rata-rata kematian lalat rumah (Musca domestica) pada jam ke-1 yaitu 8 ekor (30\%), jam ke-12 yaitu 9 ekor (35\%) dan jam ke-24 yaitu 11 ekor (42\%) Konsentrasi $5 \%$ memiliki rata-rata kematian lalat rumah (Musca domestica) pada jam ke-1 yaitu 13 ekor (51\%), jam ke-12 yaitu 14 ekor $(57 \%)$ dan jam ke24 yaitu 17 ekor (66\%). Kematian lalat rumah (Musca domestica) pada konsentrasi $7,5 \%$ filtrat daun sukun menunjukkan rata-rata pada pengamatan jam ke-1 yaitu 15 ekor (58\%), jam ke-12 yaitu 18 ekor (71\%), serta jam ke-24 yaitu 21 ekor (84\%). Hal ini menunjukkan bahwa terjadi peningkatan jumlah kematian lalat rumah (Musca domestica) seiring dengan semakin tingginya konsentrasi filtrat daun sukun (Artocarpus altilis) serta lamanya waktu pengamatan. Pada kontrol tidak terdapat jumlah kematian pada lalat rumah (Musca domestica) Hal ini serupa dengan penelitian oleh Hadawiah (2017) yang menyatakan bahwa pada konsentrasi kontrol tidak mempengaruhi kematian lalat.

Daun sukun (Artocarpus altilis) memiliki kandungan aktif yang dapat menyebabkan kematian pada lalat rumah (Musca domestica) seperti senyawa flavonoid, saponin, dan tanin (Hadawiah, 2017). Hal ini dibuktikan dengan uji bahan aktif cairan daun sukun (Artocarpus altilis) di Laboratorium Balai Penelitian dan
Konsultasi Industri Surabaya-Jawa Timur diperoleh senyawa Flavonoid sebesar $1,88 \%$, Saponin sebesar 2,26\%, dan Tanin sebesar 1,05\%. Kandungan senyawa tersebut mampu mengakibatkan kematian lalat rumah (Musca domestica). Senada dengan penelitian yang dilakukan oleh Hadawiah (2017) yang berjudul Pengaruh Filtrat Daun Sukun (Artocarpus altilis) Terhadap Mortalitas Lalat Buah (Bactrocera dorsalis) dengan hasil mampu membunuh lalat karena memiliki kandungan senyawa flavonoid, saponin, dan tanin.

Tabel 2

NILAI UJI BEDA (KRUSKAL WALLIS)

\begin{tabular}{|c|c|}
\hline $\begin{array}{c}\text { NO WAKT } \\
\text { U }\end{array}$ & $\begin{array}{l}\text { Asym } \\
\text { p. Sig }\end{array}$ \\
\hline 1. 1 jam & 0,000 \\
\hline 2. $12 \mathrm{jam}$ & 0,000 \\
\hline 3. 24 jam & 0,000 \\
\hline
\end{tabular}
menggunakan SPSS 16.0 dengan hasil uji normalitas menggunakan saphiro wilk terlebih dahulu dengan hasil menunjukkan bahwa $\mathrm{p}<0,05$ yang berarti data tidak berdistribusi normal, sehingga pengujian dilakukan menggunakan uji kruskal wallis. Hasil dari pengujian tersebut pada jam ke- 1 , dan jam ke- 12, dan jam ke- 24 menunjukkan hasil $\mathrm{p}=0,000$ yang artinya bahwa ada perbedaan rata-rata kematian lalat rumah (Musca domestica) pada berbagai konsentrasi setiap perlakuan. Hal ini sejalan dengan penelitian Baiq, et all tahun 2017 yang menunjukkan hasil $0,000<(p=0,05)$ maka filtrat rimpang jeringo dan serai wangi memiliki potensi sebagai insektisida.

Tabel 3

NILAI LC50 FILTRAT DAUN SUKUN (ARTOCARPUS ALTILIS) TERHADAP KEMATIAN LALAT RUMAH (MUSCA DOMESTICA)

\begin{tabular}{cccc}
\hline Waktu & Estimate & $\begin{array}{l}\text { Lower } \\
\text { Bound }\end{array}$ & $\begin{array}{l}\text { Upper } \\
\text { Bound }\end{array}$ \\
\hline 1 jam & 5,189 & 4,270 & 6,653 \\
\hline $\begin{array}{c}12 \\
\text { jam }\end{array}$ & 3,930 & 3,251 & 4,583 \\
\hline $\begin{array}{c}24 \\
\text { jam }\end{array}$ & 3,086 & 2,522 & 3,554 \\
\hline
\end{tabular}


Lethal Concentration (LC50) merupakan dosis yang mematikan $50 \%$ hewan uji jika diberikan melalui mulut atau diserap melalui kulit bahkan terhisap melalui pernafasan (Ditjen, P2\&PL., 2012). Toksisitas filtrat daun sukun (Artocarpus altilis) terhadap lalat rumah (Musca domestica) yaitu menggunakan Lethal Concentration (LC50). Cara menentukan dengan menghitung jumlah kematian lalat rumah (Musca domestica) setelah dilakukan pemaparan filtrat daun sukun (Artocarpus altilis) pada jam ke 1, 12, dan 24 jam. Berdasarkan hasil pengolahan data pada uji probit untuk nilai LC50, didapatkan hasil pada jam pertama (1 jam) dengan konsentrasi $5,189 \%$ dapat menyebabkan kematian lalat rumah (Musca domestica) sebesar $50 \%$ dengan konsentrasi terendah $4,270 \%$ dan konsentrasi tertinggi yaitu $6,653 \%$. Selanjutnya pada jam ke duabelas (12 jam) didapatkan hasil konsentrasi sebesar 3,930\% dapat menyebabkan kematian lalat rumah (Musca domestica) sebesar $50 \%$ dengan konsentrasi terendah 3,251\% dan konsentrasi tertinggi sebesar $4,583 \%$. Hasil probit pada jam ke dua puluh empat (24 jam) didapatkan konsentrasi sebesar 3,086\% dapat menyebabkan kematian lalat rumah (Musca domestica) sebesar $50 \%$ dengan konsentrasi terendah $2,522 \%$ dan konsentrasi tertinggi sebesar 3,554\%.

Pada konsentrasi 3,086\% dengan waktu pengamatan 24 jam merupakan konsentrasi dengan waktu pengamatan yang paling efektif dalam membunuh $50 \%$ hewan uji lalat rumah (Musca domestica). Menurut Nurhayati (2018) menyatakan jika nilai LC50 semakin rendah, maka tingkat toksisitas semakin tinggi. Pemaparan dari hasil penelitian nilai LC50 tersebut sesuai dengan pernyataan bahwa nilai LC50 semakin rendah yang berarti efektivitasnya semakin baik karena dengan menggunakan jumlah bahan baku yang sedikit dapat menghasilkan daya bunuh yang tinggi. Kematian lalat rumah (Musca domestica) ini disebabkan oleh kandungan senyawa aktif dalam filtrat daun sukun (Artocarpus altilis) sebagai racun alami. Senyawa aktif tersebut adalah senyawa flavonoid, saponin, dan tanin yang mampu dalam membunuh rumah (Musca domestica). Kematian lalat rumah (Musca domestica) ini disebabkan oleh kandungan senyawa aktif dalam filtrat daun sukun (Artocarpus altilis) sebagai racun alami. Senyawa aktif tersebut adalah senyawa flavonoid, saponin, dan tanin yang mampu dalam membunuh rumah (Musca domestica).

\section{KESIMPULAN}

1. Semakin besar konsentrasi filtrat daun sukun maka semakin besar pula jumlah kematian lalat rumah (Musca domestica) serta pada kelompok kontrol tidak terdapat jumlah kematian lalat rumah (Musca domestica).

2. Pengukuran rata-rata suhu pada jam ke-1 yaitu $30,6^{\circ} \mathrm{C}$, jam ke- 12 dan jam ke- 24 yaitu $30,5^{\circ} \mathrm{C}$ serta rata-rata kelembaban jam ke-1, jam ke-12, dan jam ke-24 yaitu $71 \%$.

3. Ada perbedaan rata-rata kematian lalat rumah (Musca domestica) dengan menggunakan berbagai konsentrasi filtrat daun sukun setiap perlakuan.

4. Pengukuran suhu dan kelembaban tidak mempengaruhi jumlah kematian lalat rumah (Musca domestica) karena masih berada normal untuk aktivitas lalat rumah, untuk suhu $20^{\circ} \mathrm{C}-34^{\circ} \mathrm{C}$ dan kelembaban diatas $45 \%$.

5. Lethal Concentration (LC50) paling efektif yang mampu membunuh lalat $50 \%$ dari hewan uji lalat rumah (Musca domestica) adalah konsentrasi 3,086\% dengan waktu pengamatan jam ke-24.

\section{SARAN}

1. Bagi peneliti lain dapat melakukan penelitian yang sama dengan membandingkan dengan tumbuhan lain yang memiliki senyawa aktif berpotensi dalam membunuh lalat rumah (Musca domestica).

2. Bagi masyarakat dapat 
memanfaatkan filtrat daun sukun sebagai bioinsektisida lalat rumah (Musca domestica) karena bersifat sangat efisien, ekonomis dan sederhana.

\section{DAFTAR PUSTAKA}

Ar, Andi Nur Rifa'atil Fahmiyah, 2016. Uji Efektivitas Ekstrak Daun Tembakau (Nicotiana tobaccum) dengan Ekstrak Daun Sirsak (Annona muricata I) Terhadap Kematian Lalat Rumah (Musca domestica). Skripsi. Makassar : Fakultas Kedokteran dan Ilmu Kesehatan Universitas Islam Negeri Alauddin.

Elisa Kumalasari, Tri Rima Setyawati, Ari Hepi Yanti, 2015. Daya Tolak Ekstrak Metanol Daun Kesum (Polygonum minus Huds.) Terhadap Lalat Rumah (Musca domestica L.). Jurnal Protobiont, 4 (2): 40-47.

Fianti, Fijrina Nur, 2019. Pengaruh Frekuensi Penyemprotan dan Konsentrasi Ekstrak Buah Majapahit (Crescentia cujete) Terhadap Mortalitas Hama Thrips sp Secara In Vitro Sebagai Sumber Belajar Biologi. Skripsi. Malang : Fakultas Keguruan dan Ilmu Pendidikan Universitas Muhammadiyah Malang.

Hadawiah, Raudatul, 2017. Pengaruh Filtrat Daun Sukun ((Artocarpus altilis (Park) Fosberg)) Terhadap Mortalitas Lalat Buah (Bactrocera dorsalis H). Skripsi. Mataram : Fakultas Ilmu Tarbiyah dan Keguruan Universitas Islam Negeri Mataram.

Immy Suci Rohyani, Evy Aryanti, \& Suripto, 2015. Kandungan Fitokimia Beberapa Jenis Tumbuhan Lokal yang Sering Dimanfaatkan Sebagai Bahan Baku Obat di Pulau Lombok. Jurnal Pros Sem Nas Masy Biodiv Indon, 1 (2). ISSN:2407-8050.

Javandira Cokorda, I Ketut Windyana, \& I Gusti Agung Suryadarmawan, 2016. Kajian Fotokimia dan Potensi Ekstrak Daun Tanaman Mimba (Azadirachta indica A. Juss) sebagai Pestisida Nabati. Denpasar: Fakultas Teknik Universitas Mahasaraswati Denpasar.

Martindah, Fitrine Ekawasti, 2016. Pengendalian Vektor pada Penyakit
Zoonotik Virus Arbo di Indonesia. Jurnal Wartazoa, 26 (4): 151-162.

Notoatmodjo, Soekidjo, 2012. Metodologi Penelitian Kesehatan. Jakarta: Rineka Cipta. Cetakan II.

Nurhayati, Siti, Tri Wahyuni Sukesi, 2018. Efek Insektisidal Ekstrak Etanol Daun Jambu Biji Putih (Psidium Guajava L) terhadap Larva Lalat Rumah (Musca domestica L). Jurnal Kesehatan Lingkungan Indonesia, 17 (2):59-62

Peraturan Menteri Kesehatan Republik Indonesia Nomor 50 Tahun 2017 Tentang Standar Baku Mutu Kesehatan Lingkungan dan Persyaratan Kesehatan untuk Vektor dan Binatang Pembawa Penyakit Serta Pengendaliannya

Prasetya Robertus Dita, Yamtana, \& Rizki Amalia, 2015. Pengaruh Variasi Lampu pada Lalat Terhadap Jumlah Lalat Rumah (Musca domestica) yang Tertangkap. Jurnal Balaba, 11 (1): 2934.

Rina, 2017. Identifikasi Protoza Usus dan Bakteri Coliform dari Berbagai Jenis Lalat di Pasar Pasir Gintung. Skripsi. Lampung: Fakultas Tarbiyah dan Keguruan Universitas Islam Negeri Raden Intan

Safirah Rahma, Nur Widodo, Mochammad Agus Krisno Budiyanto, 2016. Uji Efektivitas Insektisida Nabati Buah Crescentia cujete dan Bunga Syzygium aromaticum Terhadap Mortalitas Spodoptera litura Secara In Vitro sebagai Sumber Belajar Biologi. Jurnal Pendidikan Biologi Indonesia, 2 (3): 265-276.

Safira Sarah, Nurmaini, Surya Dharma, 2015. Hubungan Kepadatan Lalat, Personal Hygiene dan Sanitasi Dasar dengan Kejadian Diare pada Balita di Lingkungan I Kelurahan Paya Pasir Kecamatan Medan Marelan. Medan : Universitas Sumatera Utara.

Yuningsih, 2016. Bioinsektisida sebagai Upaya Re-Harmonism Ekosistem. Yogyakarta : Fakultas Keguruan dan Ilmu Pendidikan Universitas Negeri Yogyakarta. 